\title{
Physico-chemical, antioxidant and sensory properties of stirred yoghurt containing Ber (Zizyphus mauritiana) fruit extract
}

\author{
Preeti and Amrita Poonia
}

Received: 12 February 2021 / Accepted: 22 July 2021 / Published online: 21 December 2021

(c) Indian Dairy Association (India) 2021

\begin{abstract}
In this study polyphenol extract (BPE) of Ber fruit (Zizyphus mauritiana) was prepared by vacuum evaporation of ethanol extract of edible portion (pulp and skin) of fruit fortified into stirred yoghurt. A ratio of $0.20 \mathrm{BPE}(\mathrm{mg} / \mathrm{g})$ to $1.0 \mathrm{BPE}(\mathrm{mg} / \mathrm{g})$ was added for yoghurt preparation. Based on various sensory attributes, stirred yoghurt with BPE $0.8 \mathrm{mg} / \mathrm{g}$ per cent was chosen as best among these samples when compared with the control stirred yoghurt. Optimized yoghurt contains $82.36 \pm 0.545 \%$ moisture, $6.45 \pm 0.08 \%$ protein, $0.98 \pm 0.001 \%$ ash, $0.1 \%$ fat, 0.026 ppm Mn, 3.85 ppm Zn, 0.9407 ppm Cu and 950 ppm Ca, respectively. Water holding capacity of the fortified yoghurt increased significantly on increasing the BPE concentration from $41.23 \pm 0.73 \mathrm{~g} / 100 \mathrm{~g}$ to $46.66 \pm 1.13 \mathrm{~g} / 100 \mathrm{~g}$. Total phenolic content increased significantly on increasing the concentration of BPE $0.8 \mathrm{mg} / \mathrm{g}$. Fortification of BPE resulted in Total Phenolic Content (TPC) of $504.4 \pm 9.3 \mu \mathrm{g} \mathrm{GAE} / \mathrm{g}$ from $216.88 \pm 9.41 \mu \mathrm{g} \mathrm{GAE} / \mathrm{g}$ in control sample. Storage period of 20 days showed non-significant losses in total phenolic content and antioxidant capacity. TPC decreased from $504.4 \pm 9.3 \mu \mathrm{g} \mathrm{GAE} / \mathrm{g}$ to $438.17 \pm 15.58 \mu \mathrm{g} \mathrm{GAE} / \mathrm{g}$ and $\%$ DPPH inhibition decreased from $74.22 \pm 2.77 \%$ to 67.4 $\pm 1.32 \%$ after 20 days storage at $4{ }^{\circ} \mathrm{C}$.
\end{abstract}

Keywords: Stirred yoghurt, Polyphenols, Antioxidant properties, Ber fruit extract, Physico-chemical properties

Department of Dairy Science and Food Technology, Institute of Agricultural Sciences,

Banaras Hindu University, Varanasi, 221005, Uttar Pradesh, India

Amrita Poonia ( $\square)$

Department of Dairy Science and Food Technology,

Institute of Agricultural Sciences, Banaras Hindu University, Varanasi221005, Uttar Pradesh, India.

Email: dramritapoonia@gmail.com
Phenolic compounds are very powerful antioxidants due to their hydrogen donating properties and presence of their phenolic hydroxyl groups. Recently these phenolic compounds has gained a significant popularity due to various beneficial properties like antioxidant, anti-mutagen, anti-inflammatory and anti-clotting etc., which is directly related to the risk reduction of cardio vascular diseases and cancer development (Fresco et al. 2010). Fruit and seeds of $Z$. jujuba are reported to have sedative flavonoids compounds such as (4- $\beta$-D-glycopyranosyl swetisin) and spinosin. Ten flavonoids were reported from Zizyphus jujube Lamk and Zizyphus spina-chisti including Querce-tin derivatives; Kaempferol 3-Orobinobioside and Kaempferol 3-O-rutinoside (Pawlowska et al. 2009). Flavonoids have been reported to have beneficial health effects including anti-inflammatory, inhibition of platelet aggregation, inhibition of mast cell histamine release, and antimicrobial activities. Thaipong et al. (2006) reported that phenols in Indian jujube was found to be comparable with fruits already reported to be high in total phenolic content $(\mathrm{mg} / 100 \mathrm{~g})$ e.g. 126-247 in guava, 125-373 in plums. Koley et al. (2011) evaluated 12 commercial cultivars of $Z$. mauritiana for their ascorbic acid (AA), total phenolics (TPH), flavonoids (TF), and total antioxidant activity (AOX). They reported that Indian jujube is a good source of ascorbic acid and total phenolics ranging from 19.54 to $99.49 \mathrm{mg} / 100 \mathrm{~g}$ and 172 to $328.6 \mathrm{mg} \mathrm{GAE} / 100 \mathrm{~g}$, respectively. Total AOX ranged from 7.41 to 13.93 and 8.01 to $15.13 \mu \mathrm{mol}$ Trolox/g in FRAP and CUPRAC, respectively.

Yoghurt is a fermented dairy product having wide popularity among consumers and can be a suitable product for fortification with various bioactive compounds. (Allegeyer et al. 2010). Addition of fruits extracts in yoghurt will increase its functionality and marketability. Addition of ber polyphenol extracts offer a new way for delivering biologically active phytochemicals to satisfy consumer interest. Therefore, this study reports the effect of addition of ber polyphenols on sensory, physico- chemical and antioxidant properties of stirred yoghurt.

Mature Ber fruits (Ziziphus mauritiana) variety Banarasi Karaka were procured from Ber orchard of Banaras Hindu University, Varanasi, Uttar Pradesh, India. Each time the fruits were procured from same orchard to maintain homogeneity in the variety of ber fruits. Spray dried skim milk powder manufactured by Anik Milk 
Products Pvt. Ltd. was procured from the local market of Varanasi. Yoghurt starter culture NCDC-144 was purchased from NDRI, Karnal in lyophilized form and were activated before inoculation. Food grade high-methoxy pectin was used for the preparation of stirred yoghurt.

Extraction of polyphenols from ber was done followed the method of Karaaslan et al. (2011) with some modifications. A total phenolic content was determined using a modified version of the Folin- Ciocalteu method (Hinneburg et al. 2006). Folin- Ciocalteu reagent $(0.5 \mathrm{~mL})$ was added to appropriately $0.5 \mathrm{~mL}$ of diluted sample to form the mixture. After that mixture was kept at room temperature for $5 \mathrm{~min}$ and then added $1.5 \mathrm{~mL}$ of sodium carbonate (20\%) with thorough mixing. The standard calibration (0.02- 0.12 $\mathrm{mg} / \mathrm{mL}$ ) curve was made using gallic acid and results were expressed as $\mu \mathrm{g}$ gallic acid equivalent ( $\mu \mathrm{gGAE} / \mathrm{g})$. The scavenging of DPPH radical was carried out according to the method described by Li et al. (2005).

Stirred yoghurt was prepared by following the modified methods of (Sun- Waterhouse, 2013; Zhou, et al. 2011). The stirred yoghurt was formulated with skim milk powder $(14.6 \% \mathrm{w} / \mathrm{w})$, stabilizer (pectin, $0.01 \% \mathrm{w} / \mathrm{w})$, table sugar $(1.0 \% \mathrm{w} / \mathrm{w})$, yoghurt starter culture $(2 \% \mathrm{v} / \mathrm{v})$ and Ber Polyphenol Extract (BPE) at varying concentrations. Various samples with different concentration of ber polyphenolic extract (BPE) were coded as below:

Treatment details:

$$
\begin{aligned}
& \mathrm{X} 2 \mathrm{~B} \text { Control })=0 \mathrm{BPE}(\mathrm{mg} / \mathrm{g}) \\
& \mathrm{XB} 2=0.20 \mathrm{BPE}(\mathrm{mg} / \mathrm{g}) \\
& 2 \mathrm{XB}=0.40 \mathrm{BPE}(\mathrm{mg} / \mathrm{g}) \\
& \mathrm{B} 2 \mathrm{X}=0.60 \mathrm{BPE}(\mathrm{mg} / \mathrm{g}) \\
& 2 \mathrm{BX}=0.80 \mathrm{BPE}(\mathrm{mg} / \mathrm{g}) \\
& \mathrm{BX} 2=1.0 \mathrm{BPE}(\mathrm{mg} / \mathrm{g})
\end{aligned}
$$

Sensory evaluation of optimized yoghurt was done using 9.0 Point-Hedonic Scale. Yoghurt samples were analyzed for color \& appearance, flavour, consistency \& mouth feel and overall acceptability after overnight storage at $4-5{ }^{\circ} \mathrm{C}$. Different physicochemical parameters such as $\%$ fat, $\%$ Acidity, $\%$ Protein, $\%$ ash content, $\%$ total solids, $\%$ moisture, viscosity, and $\mathrm{pH}$ were determined as per the methods described by Rangana (2001). Minerals were determined using Atomic Absorption Spectroscopy (Thermo Fisher Scientist-IN). Total phenolic content of stirred yoghurt was analysed by Folin-Ciocalteau method Xia et al. (2010) with some modifications. Antioxidant activity was accounted in terms of percent of DPPH inhibition method Nishino et al. (2000). Textural parameters of BPE fortified yoghurt were analyzed using Texture Analyzer (TA.XT plus texture profile analyzer, Stable
Micro System Ltd, Model TA-XT plus, UK) with probe back extrusion Rig $35 \mathrm{~mm}$ Disc. Water holding capacity of yoghurt was determined by method of Isanga et al. (2009). The yoghurt susceptibility to syneresis (STS) was measured by placing a 100 $\mathrm{ml}$ of yoghurt sample on a filter paper placed on a funnel. After 6 $\mathrm{h}$ of drainage, the volume of the whey collected in a beaker was measured and used as an index of syneresis.

The data of the analyses were pooled and averaged and the mean and standard deviation were calculated using MS Excel software and an analysis of variance (one-way ANOVA) and differences at $(\mathrm{p}<0.05)$ were considered significant

Concentrated ethanolic extract of ber homogenate (pulp including skin) was prepared by vacuum evaporation. The total phenolic content of concentrated extract prepared from edible portion (skin and peel) of variety Banarasi Kadaka was found to be $325.20 \pm$ $25.43 \mu \mathrm{g} \mathrm{GAE} / \mathrm{ml}, \%$ DPPH, $71.09 \pm 1.89$, ascorbic acid, $86.38 \pm$ $2.69(\mathrm{mg} / 100 \mathrm{~g})$, respectively. Minimum changes in physicochemical properties of extract were observed during recommended storage at $-20^{\circ} \mathrm{C}$. Similarly, Koley et al. (2011) reported the total phenolic content of Indian Jujube (Zizyphus mauritiana Lamk.) ranging between 172 to $328.6 \mathrm{mg} \mathrm{GAE} / \mathrm{g}$ among various cultivars. Thaipong et al. (2006) also reported that Ber is found to be comparable with fruits already reported to be high in TPC like

Table 1 Physico-chemical, antioxidant and texture analysis BPE fortified stirred yoghurt

\begin{tabular}{ll}
\hline Composition & $\begin{array}{l}\text { Optimized(BPE@0.8\%) } \\
\text { fortified yoghurt }\end{array}$ \\
\hline pH & $4.88 \pm 0.03$ \\
Acidity (\% lactic acid) & $0.86 \pm 0.02$ \\
Total solids & $15.33 \pm 0.25$ \\
Moisture (\%) & $82.36 \pm 0.54$ \\
Protein (\%) & $6.45 \pm 0.08$ \\
Ash (\%) & $0.98 \pm 0.001$ \\
Fat (\%) & $0.10 \pm 0.08$ \\
Mn (ppm) & $0.026 \pm 0.01$ \\
Zn (ppm) & $3.85 \pm 0.03$ \\
Cu (ppm) & $0.94 \pm 0.01$ \\
Ca(ppm) & $950 \pm 0.02$ \\
Water holding capacity(ml/100ml) & $46.42 \pm 1.03$ \\
Susceptibility to syneresis $(\mathrm{g} / 100 \mathrm{~g})$ & $42.91 \pm 1.84$ \\
Total phenolic content $(\mu \mathrm{g} \mathrm{GAE} / \mathrm{g})$ & $504.4 \pm 9.30$ \\
DPPH inhibition $(\%)$ & $74.22 \pm 2.77$ \\
Water holding capacity(ml/100ml) & $46.42 \pm 1.03$ \\
Texture profile of BPE fortified & stirred yoghurt \\
Firmness (g) & $44.07 \pm 2.83$ \\
Consistency (g sec) & $893.493 \pm 16.0$ \\
Cohesiveness (g) & $46.56 \pm 6.95$ \\
Index of viscosity (g sec) & $105.39 \pm 7.62$ \\
& \\
\hline Data represent Mean \pm standard deviation & \\
\hline
\end{tabular}

Data represents Mean \pm standard deviation of 3 replications 
Table 2 Effect of BPE concentration on various properties of stirred yoghurt

\begin{tabular}{|c|c|c|c|c|c|c|c|}
\hline $\begin{array}{l}\text { Level of } \\
\text { incorporation } \\
\mathrm{BPE}(\mathrm{mg} / \mathrm{g})\end{array}$ & $\mathrm{pH}$ & $\begin{array}{l}\text { Acidity (as } \\
\% \text { lactic } \\
\text { acid) }\end{array}$ & $\begin{array}{l}\text { Total } \\
\text { solids (\%) }\end{array}$ & $\begin{array}{l}\text { WHC } \\
(\%)\end{array}$ & $\begin{array}{l}\text { Susceptibility } \\
\text { to synersis } \\
\text { (ml/100ml) }\end{array}$ & $\begin{array}{l}\text { DPPH } \\
\text { inhibition } \\
(\%)\end{array}$ & $\begin{array}{l}\text { TPC } \\
(\mu \mathrm{g} \text { GAE/g) }\end{array}$ \\
\hline 0 & $4.83 \pm 0.04$ & $1.09 \pm 0.03$ & $14.83 \pm 0.50$ & $41.23 \pm 0.73^{\mathrm{a}}$ & $45.15 \pm 0.59^{\mathrm{a}}$ & $23.26 \pm 6.00^{\mathrm{e}}$ & $216.88 \pm 9.41$ \\
\hline 0.2 & $4.87 \pm 0.07$ & $0.97 \pm 0.02$ & $15.00 \pm 0.36$ & $41.09 \pm 0.55^{a}$ & $42.57 \pm 1.11^{\mathrm{b}}$ & $60.33 \pm 5.07^{\mathrm{d}}$ & $299.95 \pm 20.05$ \\
\hline 0.4 & $4.85 \pm 0.01$ & $0.92 \pm 0.02$ & $14.97 \pm 0.21$ & $45.77 \pm 1.01^{\mathrm{a}}$ & $44.13 \pm 0.45^{\mathrm{ab}}$ & $66.59 \pm 1.56 \mathrm{~cd}$ & $346.53 \pm 19.42$ \\
\hline 0.6 & $4.88 \pm 0.02$ & $0.87 \pm 0.02$ & $15.07 \pm 0.31$ & $46.34 \pm 0.67^{b}$ & $43.71 \pm 0.50^{\mathrm{ab}}$ & $70.49 \pm 3.04 \mathrm{bc}$ & $473.16 \pm 15.92$ \\
\hline 0.8 & $4.88 \pm 0.03$ & $0.86 \pm 0.02$ & $15.33 \pm 0.25$ & $46.42 \pm 1.03^{b}$ & $42.91 \pm 1.84^{b}$ & $74.22 \pm 2.77 \mathrm{ab}$ & $504.4 \pm 9.30$ \\
\hline 1.0 & $4.86 \pm 0.09$ & $0.81 \pm 0.02$ & $15.37 \pm 0.25$ & $46.66 \pm 1.13^{b}$ & $45.177 \pm 1.21^{\mathrm{a}}$ & $80.35 \pm 1.18 \mathrm{a}$ & $525.87 \pm 7.86$ \\
\hline
\end{tabular}

Mean \pm S.D; means with different superscripts in a column differ significantly $(\mathrm{p}<0.05)(\mathrm{n}=3)$

guava and plums. Koley et al. (2016) reported that Ber fruit is a good source of ascorbic acid and total penolics ranged from 19.54 to $99.49 \mathrm{mg} / 100 \mathrm{~g}$ and 172 to $328.6 \mathrm{mg} \mathrm{GAE} / 100 \mathrm{~g}$, respectively. The ferric reducing antioxidant power (FRAP) and cupric reducing antioxidant capacity (CUPRAC) of Ber fruit were ranged from 7.41 to 13.93 and 8.01 to $15.13 \mu \mathrm{mol}$ Trolox/g, respectively.

Variant 2BX was found to have highest sensory preference, while $2 \mathrm{XB}$ has the lowest values. The value for X2B (control) sample was almost same for overall acceptability as $2 \mathrm{BX}$. The change in the color and appearance was found to be significant $(\mathrm{p}<0.05)$ over various added concentrations of BPE in yoghurts. The flavor of stirred yoghurt was found to be changed nonsignificantly ( $p>0.05)$. Sample $2 B X$ had highest sensory score while XB2 had the lowest value. At higher concentrations, the flavor may be enhanced and appreciated up to a certain concentration. The yoghurt variant with highest overall acceptability containing $0.80 \mathrm{BPE}(\mathrm{mg} / \mathrm{g})$ other than control $(0 \%$ extract) was chosen as optimized yoghurt for further study.

Table 1 shows the proximate analysis of optimized yoghurt. The mineral composition in terms of $\mathrm{Mn}, \mathrm{Zn}, \mathrm{Cu}$ and $\mathrm{Ca}$ for $\mathrm{BPE}$ fortified yoghurt was found to be comparable to literature values for yoghurts (Segarra et al. 2000). Optimized yoghurt contained total phenolic content 504.4 \pm 9.30 ( $\mu \mathrm{g} \mathrm{GAE} / \mathrm{g})$, DPPH inhibition $74.22 \pm 2.77 \%$, respectively. Based on sensory scores for consistency, the control and optimized yoghurt were selected for the textural analysis. The peak force during the first compression cycle is defined as firmness. The firmness of control yoghurt was found to be significantly higher $(\mathrm{p}<0.05)$ than extract fortified yoghurts and ranged between 39.46 and $94.73 \mathrm{~g}$. Optimized and control yoghurt were analyzed for consistency. The firmness of the yoghurt was found to be inversely proportional to the concentration of extract. This can be attributed to the low fat amounts and the natural properties of the extract. Consistency of control sample i.e. $1736 \pm 46.92 \mathrm{~g} \mathrm{sec}$. was significantly higher than extract fortified samples, $893.493 \pm 16.0 \mathrm{~g}$ $\sec (\mathrm{p}<0.05)$. Cohesiveness of control sample $(66.11 \pm 3.27 \mathrm{~g})$ was significantly higher $(\mathrm{p}<0.05)$ than fortified yoghurt samples. Index of viscosity was found to be maximum for control sample $180.15 \mathrm{~g}$. sec. Index of viscosity was $107.29 \mathrm{~g}$. sec with addition of $0.4 \mathrm{mg} / \mathrm{g}$ BPE which shows significant decrease i.e. $105.39 \mathrm{~g}$. $\mathrm{sec}$ with addition of $1.0 \mathrm{mg} / \mathrm{g}$ BPE in yoghurt.

It was reported that the higher the levels of solids in the yoghurt mix, the greater the viscosity/consistency of the end product (Tamime \& Robinson, 1999). In this study, the level of total soluble solids of yoghurt mix was maintained $14.83 \pm 0.50$, before the addition of the BPE. The concentration of extract up to $1.0 \mathrm{mg} / \mathrm{g}$ does not show a significant change in $\mathrm{pH}(\mathrm{p}>0.05)$ but a slight decline in acidity was noticed on increasing the concentration of extract, which can be attributed to the natural acidity of the fruit. This change was found to be significant $(p<0.05)$. Similar observations were reported by (Yadav et al. 2016). They observed that $\mathrm{pH}$ and acidity are found to be inversely effected on addition of grape peel extract in the stirred yoghurt. Total solids changes with increase in BPE concentration in stirred yoghurt but this change was not significant ( $>00.05)$. Generally, the water holding capacity (WHC) of control as well as fortified yoghurt were low and addition of pectin $(0.01 \%)$ may have improved the hydration behavior. $\mathrm{A}(\mathrm{p}<0.05)$ significant increase in water holding capacity was observed on increasing the extract concentration in stirred yoghurt. The trend of increase was maximum at the lower level of extract addition and got stable at higher level. The effect of addition of BPE showed significant $(\mathrm{p}<0.05)$ effect on syneresis.

In present study, polyphenol extract from Ber fruit's edible part (pulp and skin) was added to the stirred yoghurt before fermentation. Sun-Waterhouse (2013) and Zhou, et al. (2011) explored two approaches of adding polyphenols into yoghurt: via the pre-fermentation approach or via the post fermentation approach. The addition of BPE to the yoghurt increased the polyphenol content significantly $(\mathrm{p}<0.05)$. The increase in the concentration of BPE positively correlates with the TPC content $\left(\mathrm{R}^{2}=0.9523\right)$. Table 2 shows the results for polyphenolic content in various samples of stirred yoghurt having different level of BPE extract. Stirred yoghurt with $1.0 \mathrm{mg} / \mathrm{g}$ BPE content was found to have maximum TPC of $525.87 \pm 7.86 \mu \mathrm{g} \mathrm{GAE} / \mathrm{g}$. Addition of BPE at the rate of $1.0 \mathrm{mg} / \mathrm{g}$ had the maximum value $(80.35 \pm 1.18 \%)$ for $\%$ DPPH inhibition. The radical scavenging capacity had increased significantly $(\mathrm{p}<0.05)$ on increasing the percentage of extract in 
the yoghurt, but these factors were not perfectly correlated ( $\mathrm{R} 2=0.7522)$.

\section{Conclusions}

From this study, it is concluded that polyphenol rich extract can be obtained from Ber (Zizyphus mauritiana) and can be successfully incorporated in stirred yoghurts for polyphenolic fortification. Polyphenol fortified stirred yoghurt, thus can contribute to meet the polyphenols requirement of the body.

\section{Funding}

Sincere thanks are extended to Institutions of Eminence (IoE) scheme, Banaras Hindu University, Varanasi (U.P) India, for financial support under Incentive to Senior Faculties under IoE.

\section{References}

Allgeyer LC, Miller MJ, Lee SY (2010) Drivers of liking for yoghurt drinks with prebiotics and probiotics. J Food Sci 75: 212-219.

Fresco P, Borges F, Marques MPM, Diniz C (2010) The anticancer properties of dietary polyphenols and its relation with apoptosis. Current Pharmaceutical Design 21:114-134

Hinneburg I, Damien Dorman HJ, Hiltunen R (2006) Antioxidant activities of extracts from selected culinary herbs and spices. Food Chem 97: 122-129.

Isanga J, Zhang G (2009) Production and evaluation of some physicochemical parameters of peanut milk yoghurt. LWT-Food Sci Technol 42: 1132-1138.

Karaaslan M, Ozden M, Vardin H, Turkoglu H (2011) Phenolic fortification of yogurt using grape and callus extracts. LWT-Food Sci Technol 44: 1065-1072.

Koley, T.K. Kaur, C, Nagal, S, Walia, S, Jaggi,S, and Sarika (2011) Antioxidant activity and phenolic content in genotypes of Indian jujube (Zizyphus mauritiana Lamk.). Arabian Journal of Chemistry. doi:10.1016/j.arabjc.2011.11.005

Koley TK, Kaur C, Nagal S, Walia S, Jaggi S (2016) Antioxidant activity and phenolic content in genotypes of Indian jujube (Zizyphus mauritiana Lamk.). Arabian J Chem 9:1044-1052.) doi: https:// doi.org/10.1016/j. arabjc.2011.11.005
Li JW, Ding SD, Ding XL (2005) Comparison of antioxidant capacities of extracts from five cultivars of Chinese jujube. Process Biochem 44:3607-3613. https://doi.org/10.1016/j.procbio.2005.03.005.

Pawlowska AM, Camangi F, Bader A, Braca A (2009) Antioxidant activity and phenolic content in genotypes of Indian jujube (Zizyphus mauritiana Lamk.). Food Chem 112: 858-862

Ranganna S (2001) Handbook of analysis of fruits and vegetable products. $2^{\text {nd }}$ ed., Tata Mc-Graw-Hill Pub. Com. Ltd., New Delhi.

Nishino T, Shibahara-Sone H, Kikuchi-Hayakawa HL, Shikawa F (2000) Transit of radical scavenging activity of milk products prepared by Millard reaction and Lactobacillus caseii strain shirota fermentation through the hamster intestine. J Dairy Sci 83: 915-92

Segarra PJ, Martýìnez M, Otero MJ, Valverde A, Lopez MA, MorenoRojas R (2000) Influence of the addition of fruit on the mineral content of yoghurts: nutritional assessment. J Food Chem 71: 8589.

Sun-Waterhouse D, Zhou J, Wadhwa SS (2013). Drinking yoghurts with berry polyphenols added before and after fermentation. Food Control 32 : 450-460.

Tamime AY, Robinson RK (1999) Yoghurt: Science and Technology. Woodhead Publishing. 25-32

Thaipong KU, Boonprakob K, Crosby L, Cisneros-Zevallos D, Hawkins B (2006) Comparison of ABTS, DPPH, FRAP and ORAC assays for estimating antioxidant activity from guava fruit extracts. J Food Comp Anal 19: 669-675

Xia EQ, Deng GF, Guo YJ, Li HB (2010) Biological Activities of Polyphenols from Grapes. Int J Mol Sci 11: 622-646

Yadav D, Kumar H, Kumar A, Jha A, Kumar P, Goyal A (2016) Optimization of polyphenolic fortification of grape peel extract in stirred yogurt by response surface methodology. Indian J Dairy Sci 69: 1-5

Zhou P, Mulvaney SJ, Regenstein JM (2006) Properties of Alaska pollock skin gelatin: A comparison with tilapia and pork skin gelatins J Food Sci 71: C313-C321 